\title{
MÉSZÁROS TAMÁS
}

\section{MEGJEGYZÉSEK PROKOPIOS „PERZSA TÖRTÉNETEIHEZ”}

\author{
(De bellis I, 2-6)*
}

\begin{abstract}
Történeti műve bevezetőjének végén Prokopios vázolja a bizánciak és a perzsák kapcsolatának történetét. A mű ezen részét (De bellis I, 2-6), mely anekdotába illő epizódokból, mesékből és kitalált történetekből áll, a kutatók a történeti hitelességet nélkülöző, szórakoztató összeállításnak tekintik. Jelen dolgozat célja, hogy bemutassa ezeket az anekdotákat, az úgynevezett „perzsa történeteket”, valamint elemezze a történetek szerkezetét és funkcióját. Véleményünk szerint Prokopios hérodotosi irodalmi technikákat alkalmaz, hogy a háborúhoz vezető erkölcsi romlást ábrázolja.
\end{abstract}

Kulcsszavak: Prokopios, perzsa háború, anekdoták, Hérodotos

A kaisareiai Prokopios főművének, a Iustinianos császár háborúit bemutató $D e$ bellisnek a szerkezeti felépítése jól kitapintható. A történeti munka, amint azt az egyes könyvek hagyományos alcíme is jelzi, a bizánciak barbár népek ellen vívott háborúinak helyszine szerint építkezik, mégpedig úgy, hogy a földrajzi kerethez képest még az események kronológiai rendje is másodlagos. Az első két könyv a perzsa háborúkat tárgyalja (De bellis $\mathrm{I}-\mathrm{II}$ = De bello Persico I-II), az újabb könyvpár a vandál háborúk eseményeit ismerteti (De bellis III-IV = De bello Vandalico I-II), a következő három könyv pedig a gót háború történéseiről számol be (De bellis V-VII = De bello Gothico I-III). ${ }^{1}$ Utóbbi esetben a háború kiemelkedő jelentősége már önmagában indokolhatja a korábbi részekhez képest megnövekedett terjedelmet, hiszen a „iustinianosi álom” megvalósításának, vagyis a hajdani Római Birodalom területi restaurációjának legfontosabb állomását egyértelműen az „itáliai szülőföld” visszahódítása jelenti.

A nyolcadik könyv látszólag látványosan szakít a korábbi szerkesztési szempontokkal: Prokopios itt már szigorúan kronológiai rendbe állítva ismerteti az eseményeket, miközben a helyszín másodlagossá válik. ${ }^{2}$ Az eltérő módszerre azonban kielégítő magyarázatot szolgáltathat az utolsó könyv datálása, illetve eltérő keletkezési körülmé-

\footnotetext{
"A tanulmány az OTKA PD 104876 jelzetű pályázat, valamint a Bolyai Ösztöndíj támogatásával készült.

1 A görög szöveget a mértékadónak tekintett kiadásból idézem: Procopii Caesariensis Opera omnia I-IV. Recognovit J. Haury. Lipsiae 1905-1913. Addenda et corrigenda adiecit G. Wirth. Lipsiae 1962-1964. Ugyancsak ezt a kiadást követem a fejezetszámok és alcímek tekintetében is, bár a beosztás sok esetben következetlen. A tulajdonneveket a Prokopiosnál használatos görög formában közlöm.

${ }^{2}$ Ennek ellenére Haury - Wirth: i. m. (1. jegyz.) a De bellis VIII mellett hozza a De bello Gothico IV alcímet. A pontatlanság nyilvánvaló, a könyv jelentős része ugyanis nem a gót háborúval foglalkozik.
} 
nyei. ${ }^{3}$ Szinte biztos, hogy a perzsák, a vandálok és a gótok elleni háborúk történetét a gót háború tizenhatodik évéig (550) bemutató könyvek együttesen kerültek kiadásra, feltehetően 550/551 körül. ${ }^{4}$ A hadjáratok jelentős részét Belisarios „titkáraként” -

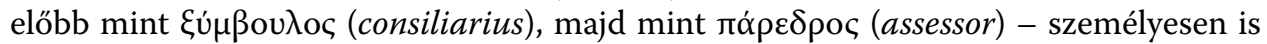
végigszolgáló Prokopios 542 és 545 között, egy huzamosabb konstantinápolyi tartózkodása során nagyjából már befejezhette müvét, melynek tényleges publikációjára - az időközben elkészült folytatással együtt - valószínűleg csak 550-ben került sor. ${ }^{5}$ Annyi bizonyos, hogy ez volt Prokopios elsőként kiadott, történetírói rangját és ismertségét megalapozó munkája. Ami viszont a mű befejezését illeti, a korábbi könyvekhez képest eltérő szerkezetű és szemléletű nyolcadik könyv közzététele jóval később, talán már 554-ben, de - a kései datálás mellett érvelő kutatók szerint - az is elképzelhető, hogy csak 557 után történt meg. ${ }^{6}$ Summa summarum: az utolsó könyv mintegy függelékül került a mü végére.

Bár a mű makrostruktúrája fentieknek megfelelően szépen kirajzolódik, az egyes könyvekre, még inkább a könyveken belüli kisebb egységekre vonatkozó szerkesztési elvek tekintetében korántsem kristálytiszta a kép. Különösen nagy kihívás elé állítja a kutatókat az első könyv prooimionját közvetlenül követő rész, a perzsa háború előzményeit bemutató történeti áttekintés értelmezése (De bellis I, 2-6). Egészen a közelmúltig nem is próbálta senki megfejteni az egymás után sorjázó, látszólag minden rendszer nélkül „összehordott”, félig-meddig mesébe illő anekdoták valódi dramaturgiai funkcióját. Anthony Kaldellis volt az első, aki az utóbbi időben több alkalommal is kitért a perzsa történetek kérdésére. Először kiváló Prokopios-monográfiájában szentelt önálló fejezetet a problémának, ${ }^{7}$ majd később - részben más szempontok szerint - még egyszer visszatért a perzsa könyvek szerepének értelmezésére. ${ }^{8}$ Kaldellis legfőbb érdeme, hogy komolyan vette a kutatók többsége által jelentéktelennek vagy mellékesnek tekin-

3 A kérdéshez általában lásd: G. Greatrex: The Dates of Procopius' Works. BMGS 18 (1994) 101-114 és J. A. S. Evans: The Dates of Procopius' Works: A Recapitulation of the Evidence. GRBS 37 (1996) 301-313.

${ }^{4}$ A datálás kérdésében nincs tudományos konszenzus. E. Kislinger: Ein Angriff zu viel. BZ 91 (1998) 49-58 szerint például a De bellis II, 4, 4-11-ben leírt barbár betörések némelyikére csak 558-ban kerülhetett sor. Cáfolja: G. Greatrex: Recent Work on Procopius and the Composition of Wars VIII. BMGS 27 (2003) 45-67.

${ }^{5}$ A keletkezési időre történő szövegszerű, belső utalásokat (pl.: De bellis I, 25, 43; II, 22, 9; V, 24, 32; VI, 5, 26) J. Haury: Procopiana. Augsburg 1891 és J. Haury: Procopiana II. Teil. München 1893 gyűjtötte össze és elemezte.

${ }^{6}$ A korai datálás mellett J. B. Bury: A History of the Later Roman Empire II. London 1923. 422 (553); E. Stein: Histoire du Bas-Empire II. Amsterdam 1949. 717 és Av. Cameron: Procopius and the Sixth Century. London - New York 1996². 8 (554), a kései mellett J. A. S. Evans: Procopius. New York 1972. 43 (557) hoz fel érveket.

${ }^{7}$ A. Kaldellis: Procopius of Caesarea. Tyranny, History, and Philosophy at the End of Antiquity. Philadelphia 2004. 62-93 (Chapter 2. Tales Not Unworthy of Trust: Anecdotes and the Persian War).

${ }^{8}$ A. Kaldellis: Procopius' Persian War: A Thematic and Literary Analysis. In: R. Macrides (ed.): History as Literature in Byzantium: Papers from the Fortieth Spring Symposium of Byzantine, University of Birmingham, March 2007. Farnham 2010. 253-273. 
tett történetfüzért, és koherens értelmezést adott a szóban forgó részekről, mégpedig a mü egészének figyelembevételével. Kaldellis elemzése tehát mindenképpen jelentős előrelépésnek számít, még úgy is, hogy egy-egy részlet vonatkozásában magunk nem mindig értünk egyet vele. A következőkben megpróbálunk felvetni néhány egyéb lehetséges szempontot a perzsa anekdoták értelmezéséhez. Ha a javaslatainkat illetően lehetnek is fenntartások, abban Kaldellishez hasonlóan magunk is biztosak vagyunk, hogy a történetek nem esetlegesen, a puszta szórakoztatás céljából kerültek a mű szövegébe. ${ }^{9}$ Mindenekelőtt azonban tekintsük át röviden, hogy mi is a vizsgálat tárgya, milyen történetekkel kezdi meg Prokopios a perzsa háborúk elbeszélését. ${ }^{10}$

II.

Miután Prokopios ismertette történetírói célkitűzését, szót ejtett művének hitelességéről, jelentőségéről, várható hasznáról, továbbá az íjász fegyvernem átalakulásán keresztül szemléltette az emberiség fejlődését, ${ }^{11}$ bevezető gondolatai zárásaképpen

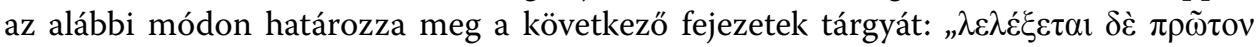

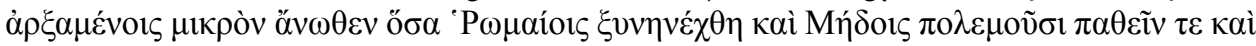
$\delta \rho \tilde{\alpha} \sigma \alpha l^{\prime \prime}{ }^{12}$

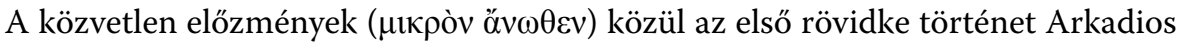
bizánci császár és Isdigerdés (I. Yazdgird) perzsa király különleges kapcsolatát ismerteti (I, 2,1-10). Mikor a császár a halála közeledtét érezte, nem akármilyen ötlettel próbálta megvédeni a birodalmát fenyegető külső és belső veszélyekkel szemben kiskorú fia, a későbbi II. Theodosios életét, egyszersmind biztosítani számára a trónt. Az egyébként nem túl éles eszűnek tartott Arkadios ugyanis úgy kívánta elejét venni mind a trónviszálynak, mind a perzsák esetleges támadásának, hogy éppen utóbbiak királyát kérte fel Theodosios törvényes gyámjának. Az pedig talán még a császár szokványosnak nem nevezhető lépésénél is különösebb, hogy a perzsa király nemcsak vállalta a feladatot, hanem példás módon eleget is tett a gyámsággal járó kötelezettségeknek, méghozzá anélkül, hogy ebből - a jó hírtől eltekintve - bármi haszna származott volna. Isdigerdés jótékony közreműködésének köszönhetően Theodosios elkerülte a féltékeny trónkövetelők jelentette veszélyt, és felnőtt korba lépve elfoglalhatta apja örökségét.

9 Vö.: Kaldellis: i. m. (7. jegyz.) 63: "Even if my specific interpretation of these stories is wrong, I still believe that we must engage them in a similar way. They should no longer be dismissed as stupid and pointless."

${ }^{10}$ Az alábbiakban a perzsa háború előzményei között az egyes történeteket ugyanabban a sorrendben tárgyaljuk, mint Kaldellis: i. m. (7. jegyz.).

${ }^{11}$ Maltretus hagyományosan idézett tartalmi összegzése szerint: "Aperit auctor propositum suum. Utilitatem, fidem ac dignitatem ostendit huius historiae. Contra antiquitatis laudatores praeposteros aetatis suae egregie facta et sagittarios defendit." Vö.: C. Maltretus SJ Presb.: Procopii Caesariensis Historiarum sui temporis libri VIII. Paris 1661-1663 (repr. Venice 1729).

12 „A közvetlen elözményekkel kezdve elöször arról lesz szó, hogy mi történt a rómaiak és a médek háborúja során, milyen vereségeket szenvedtek és milyen gyözelmeket arattak a felek." 
Később aztán már nem alakult ilyen fényesen a két birodalom viszonya, legalábbis erről árulkodik a következő történet (I, 2, 11-15). Uararanés/V. Bahrām perzsa király - közelebbről nem részletezett okokból - jelentős serege élén támadást intézett a bizánci területek ellen. Hogy végül mégsem tört ki háború a felek között, mindössze egy véletlennek köszönhető. Theodosios ugyanis a szokásos összetételű követség helyett - közelebbről szintén nem részletezett okokból - éppen a római hadsereg legfőbb vezetőjét, a magister militum per Orientem (ó $\tau \tilde{\eta} \varsigma ~ \check{~} \omega \sigma \tau \rho \alpha \tau \eta \gamma o ́ \varsigma)$ rangban szolgáló Anatoliost küldte tárgyalni a perzsák elé, ${ }^{13}$ ráadásul egymagában. A folytatás már-már hőseposzba kívánkozik: mikor Anatolios a perzsák közelébe ért, lováról leszállva, az ellenséges katonák gyürüjében, gyalogosan járult a király színe elé. Nagy lélekjelenlétről tanúbizonyságot tevő személyes fellépése olyannyira meglepte és lenyügözte Uararanést, aki már a követ

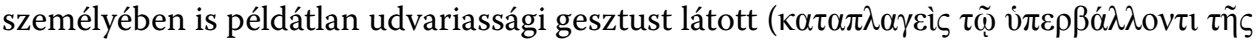
$\tau \iota \mu \tilde{\eta} \varsigma)$, hogy a perzsák visszavonultak saját földjükre, és változtatás nélkül elfogadták a rómaiak békefeltételeit.

A sorban következő harmadik történet szintén egy perzsa katonai vállalkozás leírásával kezdődik, de a szereposztás ezúttal eltér az eddigiektől. A bizánciak most csak közvetve jelennek meg - Zénón császár követe, Eusebios történetesen az aktuális perzsa király, Perozés/Pērōz társaságában tartózkodik a szóban forgó hadjárat idején -, a perzsák ellenfelei ugyanis az ephthaliták, más néven fehér hunok (I, 3, 1; I, 3, 8-22). Mindez arra is alkalmat szolgáltat Prokopiosnak, hogy egy néprajzi kitérőben röviden bemutassa a barbár ephthaliták népét (I, 3, 2-7). Ami a hadjáratot - pontosabban a két hadjáratot - illeti, a vállalkozás a perzsák teljes katonai és erkölcsi kudarcával végződik. Az ephthaliták mindkét esetben csellel járnak túl ellenfelük eszén. Az első alkalommal egy járhatatlan, sűrü erdőbe csalják, majd bekerítik a perzsákat, akik csak későn ismerik fel a valódi veszélyt. Így aztán Eusebios hiába próbálja megállítani a csapdába csalt oroszlán példázatával az ellenségét meggondolatlanul üldöző Perozést - már túl késő. A király, hogy saját életét és seregét mentse, nemcsak képletesen kényszerül térdre az ephthaliták előtt, a szabad elvonulás egyik feltétele ugyanis éppen az, hogy Perozésnek saját magát megalázva le kell borulnia ellenfele előtt. Végül tanácsadói javaslatára úgy sikerül megmenekülnie a szégyentől, hogy valójában nem az ephthalita király, hanem - ősi perzsa szokás szerint - a felkelő nap előtt borul le, de ezzel formálisan eleget tesz a győztesek követelésének. A másik békefeltétel teljesítése még csak „technikai problémát" sem okoz: Perozés minden további nélkül hajlandó eskü alatt megígérni, hogy többé nem vonul a fehér hunok ellen. Igaz, a folytatásból kiderül, hogy az eskü megszegése sem jelent számára nehézséget, hiszen hamarosan újabb hadjáratot indít. A második expedíció fóbb elemeit tekintve mintha csak a korábbi, kudarcba fulladt hadjáratot ismételné (I, 4, 1-13; I, 4, 32-33). A perzsa sereg ugyanúgy támadást intéz az ephthaliták ellen, a fehér hunok ugyanúgy csellel kerekednek felül a túlerőn. Az egyetlen, ám annál fontosabb különbséget egyedül a történet végkifejlete mutatja: az óvatlan perzsa kato-

13 Anatolios (működése kb. 421-451) hadvezér és államférfi. Először 433 és 446 között nyeri el a magister militum per Orientem rangot, közben 440-ben consul. Vö.: PLRN II, 84-86. s. v. Anatolius 10. 
nák az ellenség üldözése közben nem veszik észre a csapdát, belezuhannak az ephthaliták vermébe, és a sereg - Perozésszal és fiaival együtt - mind egy szálig elpusztul.

Prokopios az események menetét ezen a ponton megszakítva egy hosszabb kitérőben meséli el olvasóinak Perozés igazgyöngyének csodálatos történetét (I, 4, 14-31). Az elbeszélés szerint a perzsa partok közvetlen közelében egy kagyló lebegett a vízben, melynek szétnyílt héja között jól látható módon egy hófehér, az átlagosnál nagyobb mére-

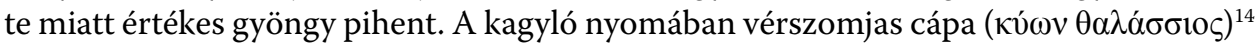
úszott a csodálatos látványtól megbabonázva. Mikor a különleges jelenség híre Perozés fülébe jutott, a király rábeszélt egy halászt, hogy busás jutalom fejében szerezze meg számára a gyöngyöt. A halász tisztában volt a veszéllyel. Végül ráállt ugyan a feladatra, de azt kérte Perozéstől, hogy ő gondoskodjon a gyermekeiről, ha a vállalkozás balul ütne ki. Ahogy az ilyen esetben várható, a halász balsejtelme valóra vált: miután utolsó erejével éppen csak ki tudta dobni a tengerből a gyöngyöt a partra, a cápa máris utolérte és végzett vele. Hogy mi lett a sorsa a gyerekeinek, arról Prokopios nem ejt szót.

Perozés halála után az egyedüliként életben maradt fia, Kabadés/I. Kavād örökölte a trónt, akinek uralkodása erősen megosztotta a perzsa népet. Az alattvalókat felháborító intézkedései miatt végül lázadás tört ki ellene, Kabadést bebörtönözték, s csak a perzsák hagyománytiszteletének köszönhetően menekült meg a kivégzéstől. A súlyos büntetést azonban nem kerülhette el: a Felejtés börtönének nevezett erődbe zárták

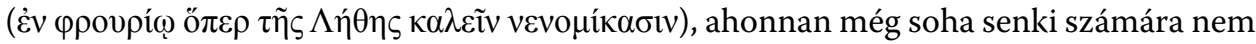
volt visszaút. Mint az elnevezés is mutatja, örök feledés volt az osztályrésze annak, aki egyszer a falak közé került: fővesztés terhe mellett többé még a nevét sem ejthette ki a száján senki. (I, 4, 43 - I, 5, 8).

Kabadés bebörtönzése arra indítja Prokopiost, hogy felidézzen egy korábbi esetet, mely $A z$ arméniaiak története című müből jutott tudomására (I, 5, 9-40). ${ }^{15}$ A legenda szerint Pakurios/II. Shāpūr perzsa király esküszegéssel és lázítással vádolta meg szövetségesét, Arsakés/ II. Arshak armeniai uralkodót. Utóbbi, hogy tisztázza magát a vádak alól, a perzsa udvarba sietett, a mindent eldöntő beszélgetés során azonban - a magusok varázsigéinek hatására - végül elismerte a vádpontokat, és terhelő vallomása következtében ő is a Felejtés börtönébe került. A történet azonban nem ér véget ezen a ponton, sőt a lényeg, ami miatt Prokopios egyáltalán belefogott az elbeszélésbe, csak most következik. Ez az egyetlen ismert eset ugyanis, amikor a perzsák megszegték a Felejtés börtöné-

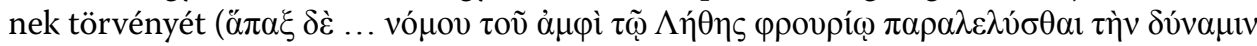

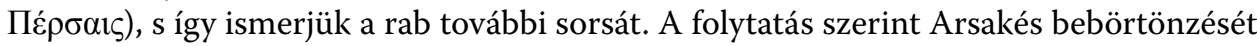
követően egy armeniai katona kitüntette magát a perzsák oldalán vívott hadjáratban.

14 Vö.: Plin. NH IX, 55, 110; Ael. NA I, 55.

15 A szöveg mértékadó kiadása: N. Garsö̈an (transl.): The Epic Histories Attributed to Pcawstos Buzand. Buzandaran Patmutciwnkc. Cambridge (Mass.) 1989. Arsakés történetét az V. könyv VII. fejezete őrizte meg. Vö.: G. Traina: Faustus „of Byzantium”, Procopius, and the Armenian History (Jacoby, FGrHist 679, 3-4). In: C. Sode - S. Takács (eds.): Novum Millennium. Studies on Byzantine History and Culture Dedicated to Paul Speck. Aldershot 1999. 405-413. 
Pakurios, aki szemtanúja volt a férfi hőstetteinek, felajánlotta, hogy kívánjon cserébe, amit csak akar, ő teljesíteni fogja a kérést. A perzsa király legnagyobb megdöbbenésére azonban busás anyagi juttatások helyett az armeniai mindössze azt kívánta, hogy kedve szerint eltölthessen egy napot Arsakés társaságában. Mivel Pakurios nem akarta megszegni adott szavát, még a törvény megszegésének árán is kénytelen-kelletlen bele-

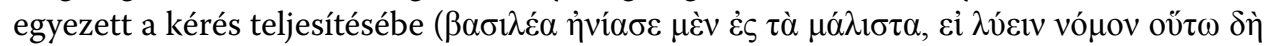

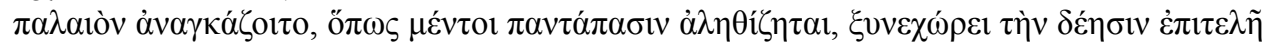
$\gamma \varepsilon v \varepsilon ́ \sigma \theta \alpha \imath)$. Aztán a régi időket idéző körülmények között, kellemesen eltöltött nap végeztével a megpróbáltatásait megelégelő Arsakés önkezével vetett véget életének.

Kabadés sorsa lényegesen szerencsésebben alakult. Előbb a börtönparancsnok bizalmába férkőző felesége ruhájában megszökött a Felejtés börtönéből, majd az ephthaliták katonai támogatásával visszaszerezte hatalmát, és bosszút állt ellenfelein (I, 6, 1-19). $\mathrm{Az}$ „újdonsült” uralkodó egyik első intézkedése az volt, hogy az ellenséges magatartásuk miatt korábban leváltott főemberek helyett saját bizalmas híveit juttatta a stratégiai szempontból leginkább fontos méltóságokhoz. Igaz, könnyelműsége miatt egy alkalommal kis híján csak törvényszegés árán tudta megtartani adott szavát, de végül szerencséjére - ezúttal - nem kényszerült a perzsa szokások semmibevételére. A történetre (I, 6, 12-16), mely egyéb szempontból is tanulságos, később még visszatérünk. Ezzel az epizóddal lényegét tekintve le is zárul a perzsa háborúk előzményeinek ismertetése, Kabadés uralkodásának második időszaka (498-531) ugyanis már részben egybeesik Iustinianos uralkodásának idejével (527-565): ez már az első két könyv tényleges tárgyául szolgáló perzsa háborúk korszaka. ${ }^{16}$

\section{III.}

Kaldellis alapos szakirodalmi áttekintése szerencsére mentesít minket attól, hogy részletesen ismertessük a korábbi kutatók álláspontját a perzsa anekdotákat illetően. ${ }^{17}$ A tudományos közvélemény általános véleményének bemutatásához elegendő, ha röviden felidézzük a visszatérően megjelenő főbb gondolatokat. Ezek szerint az anekdoták nem rendelkeznek történeti hitelességgel, ${ }^{18}$ az egyes epizódok bemutatásával Prokopios elsődleges célja a szórakoztatás volt, ${ }^{19}$ a szerző mindössze a klasszikus hagyomány naiv elképzeléseiből űz csúfot, beszámolóját - olvasmányossága ellenére - aligha kell komo-

16 Ennek megfelelően a következő fejezet (I, 7) már Kabadés támadásáról és Amida elestéről számol be.

${ }^{17}$ Lásd Kaldellis: i. m. (7. jegyz.) 62-65.

${ }_{18}$ Cameron: i. m. (6. jegyz.) 156: "It does not amount too much real history - rather to a mixture of anecdote and notices taken from a variety of sources, mixed in with a fair amount of literary dressing."

${ }_{19}$ G. Greatrex: Rome and Persia at War, 502-532. Leeds 1998. 74: "The purpose of the introductory chapters was to entertain the reader, rather than to examine the events." 
lyan vennünk. ${ }^{20}$ Mindez, ha van is némi igazság az egyes kritikai észrevételekben, véleményünk szerint távolról sem fedi a valóságot.

Ami a történeti pontosság kérdését illeti, bajosan lehet vita: Prokopios - akarva-akaratlan - nyilvánvalóan több helyen is téves adatot közöl. Az Arkadios-történet hitelességét már kortárs szerző is megkérdőjelezte ${ }^{21}$ és a bizonytalanság mára sem szűnt meg. ${ }^{22}$ Hasonlóan zavaros a második epizód kronológiája: a Uararanésnek tulajdonított támadás - mely Prokopios állításával ellentétben komoly összecsapásokkal járt - valószínűleg 420-422-ben történt, míg Anatolios a magister militum per Orientem tisztséget minden bizonnyal csak egy évtizeddel később nyerte el. ${ }^{23}$ Szintén egyértelmű, hogy Prokopios tévesen hagyományozza a Perozés halála után trónra lépő perzsa királyok sorrendjét. Az ephthaliták áldozatául esett uralkodót ugyanis először testvére, Blasés/ Balāsh követte a trónon (484-488), csak utána következett Kabadés (488-496) - először -, majd Kabadés bebörtönzése után fivére, Zāmāsp (496-498) - róla Prokopios nem is tud -, végül ismét, immár másodszor Kabadés (498-531). ${ }^{24}$ Az apró részletek és a nyilvánvalóan mesébe illő történetek (az igazgyöngy és a cápa, a magusok varázspraktikái stb.) valóságtartalmára nem szükséges külön kitérnünk, ezek hitelességét ugyanis időnként maga Prokopios is kétségbe vonja. ${ }^{25}$ Mindebből egyenesen következik, hogy Prokopios, bár a szükséges tények és adatok minden bizonnyal rendelkezésére álltak, ${ }^{26}$

${ }^{20}$ R. Scott: The Classical Tradition in Byzantine Historiography. In: M. Mullett - R. Scott (eds.): Byzantium and the Classical Tradition. Birmingham 1981. 73: "He [ti. Prokopios] is in fact playing a sophisticated game by poking fun at his classical models", majd később: "his prologue makes highly enjoyable light reading, but is not meant to be taken too seriously."

${ }^{21}$ Agathias saját állítása szerint (IV, 26, 3-8) csak Prokopiosnál olvasott a történetről, egyébként pedig különösnek találja, hogy egy keresztény uralkodó ilyen fontos ügyben éppen pogány királyhoz folyamodik segítségért.

${ }^{22}$ A történet hitelességét a tudományos kutatás eltérően ítéli meg. Vö.: Av. Cameron: Agathias on the Sassanians. DOP 23-24 (1969-1970) 67-183; K. G. Holum: Theodosian Empresses: Women and Imperial Dominion in Late Antiquity. Berkeley 1982. 83; R. C. Blockley: East Roman Foreign Policy. Formation and Conduct from Diocletian to Anastasius. Leeds 1992. 51-52.

${ }^{23}$ Cameron: i. m. (22. jegyz.) 151-152.

${ }^{24}$ Vö. a korszakra vonatkozó rövid áttekintések közül: N. Frye: The Political History of Iran under the Sasanians. In: E. Yarshater: The Cambridge History of Iran 3 (1). The Seleucid, Parthian, and Sasanian Periods. Cambridge 1983. 116-180; N. Garsö̈an: Byzantium and the Sasanians. In: E. Yarshater: The Cambridge History of Iran 3 (1). The Seleucid, Parthian, and Sasanian Periods. Cambridge 1983. 568-592; Z. Rubin: The Sasanid Monarchy. In: Av. Cameron - B. Ward-Perkins - M. Whitby (eds.): The Cambridge Ancient History XIV. Late Antiquity: Empire and Successors, A. D. 425-600. Cambridge 2000. 638-661.

${ }^{25}$ Prokopios több esetben is expressis verbis elhatárolódik a mondottaktól. Először Perozés halála kap-

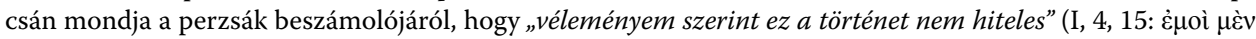
ở $\pi \mathrm{\imath} \tau \dot{\alpha} \lambda \dot{\varepsilon} \gamma o v \tau \varepsilon \varsigma)$, majd az igazgyöngy történetét kezdi úgy, hogy „hátha akad olyan olvasó, aki nem tartja

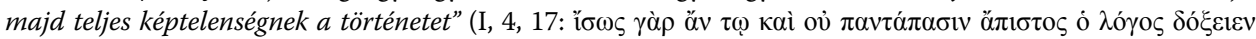
عivol).

${ }^{26}$ Az Anatolios-Uararanés történet kapcsán találóan fogalmaz Kaldellis i. m. (7. jegyz.) 68: "Procopius had first hand experience of too many wars to believe a story like that. He almost certainly had more information about the war of 420-422 but chose to produce this stylized episode instead. Its truth resides not in the facts that it relates but in what it tells us about the framework of the military encounters between Rome and Persia." 
nem azt tartotta fontosnak, milyen sorrendben következtek egymás után a perzsa uralkodók, akiknek személye nagy valószínűséggel különben is ismeretlen - és, ha szabad ilyet mondani, érdektelen - volt az olvasók többsége számára, vagy hány tagja volt a Uararanéshez menesztett követségnek: a történeti háttér ezúttal mindössze díszlet. És ahogy a díszlet - mintha csak színházban lennénk - végső soron az előadás szolgálatában áll, az előadás sikerét hivatott elősegíteni, úgy a történeti háttér is csak mellékes eszköznek tünik ahhoz képest, amit a szerző történeteivel a perzsákról közölni kíván. Prokopiost vélhetően nem a tudatlanság, vagy a hamisítás szándéka vezérli: mindössze a lényegtelennek ítélt adatokat alárendeli mondanivalójának, a jelentéktelen tényeket annak, amit közönsége szempontjából valóban fontosnak tart.

Ami mármost a többi kritikai észrevételt illeti, a felsoroltak közül magunk egyet sem találunk megalapozottnak. Kétségtelen, hogy az olvasó szórakoztatása csakugyan lényeges szempont volt a szerző számára - de csak amennyiben minden valamirevaló író arra törekszik, hogy művét élvezettel forgassák. Mindamellett abban még a kritikusok is egyetértenek, hogy Prokopios történeti munkája jóval több, mint a népszerüséget hajhászó olcsó komédiázás, zavaros és hihetetlen történetek laza felsorolása pusztán az öncélú szórakoztatás céljából. Nincs ez másképpen a perzsa történetek esetében sem: meglehet, hogy nem találunk mindenki számára elfogadható összefüggést az anekdoták között, de ha beérjük annyival, hogy mindössze könnyed szórakoztatásról van szó, ne Prokopiost hibáztassuk.

A klasszikus hagyomány magabiztos ismerete és fölényes kezelése minden bizánci szerzővel szemben joggal támasztott elvárás. ${ }^{27}$ Különösen igaz ez a közismerten széles műveltséggel és olvasottsággal rendelkező Prokopiosra, aki társaihoz hasonlóan sokkal inkább követendő mintának tekintette, mintsem kigúnyolta a műfajában jelentőset alkotó antik szerzőket. A Prokopiosnál nagy számban megtalálható Hérodotos-, Thukydidés-, Arrhianos-hivatkozások (a nyelvi allúzióktól kezdve a reminiszcenciákon át a szó szerinti átvételekig) ennek a tiszteletnek a megnyilvánulásai, melyek a formán keresztül teremtenek valamilyen kapcsolatot a megidézett szerzővel és mondanivalójával. Bár ez a kapcsolat sokrétű és sokféle lehet, Prokopios szándéka semmiképpen sem az, hogy görbe tükröt tartva eléjük csúfot űzzön példaképeiből, ez ugyanis teljes mértékben idegen lenne a bizánci történetírás szellemétől. ${ }^{28}$

Fentebb idézett véleményekkel ellentétben tehát - mint mondtuk - magunk Kaldellis nézeteit osztjuk: szerintünk sincs szó holmi l’art pour l’art tréfálkozásról, ${ }^{29}$ az anek-

27 Ezúttal már csak terjedelmi okokból sem térhetünk ki a klasszikus hagyomány bizánci megjelenésének összetett kérdésére, de megteszi mindezt Kaldellis: i. m. (7. jegyz.) 17-61 (Classicism and Its Discontents), különösen 24-38 (A Typology of Classicism).

${ }^{28}$ Vö.: Moravcsik Gy.: Klassizismus in der byzantinischen Geschichtsschreibung. In: P. Wirth (ed.): Polychronion. Festschrift Franz Dölger zum 75. Geburtstag. Heidelberg 1966. 366-377; H. Hunger: On the Imitation (MIMH $\Sigma \mathrm{I} \Sigma$ ) of Antiquity in Byzantine Literature. DOP 23-24 (1969-1970) 15-38.

${ }^{29}$ Kaldellis: i. m. (7. jegyz.) 64: "We must read these stories with the utmost seriousness." 
dotáknak, ahogyan azt a kortársak is pontosan érzékelték, ${ }^{30}$ megvan a maguk nagyon is komoly funkciója. ${ }^{31}$ A bevezetés alapvető célja - ebben is egyetértünk Kaldellisszel -, hogy bemutassa a mindkét felet egyaránt érintő erkölcsi hanyatlás folyamatát - ebből a szempontból rómaiak és barbárok között nincs különbség -, mely elkerülhetetlenül zsarnoki hatalom kialakulásához, végül pedig háborúhoz vezet. Ugyanakkor - Kaldellisszel ellentétben - a perzsa történetek értelmezése szempontjából nem tartjuk relevánsnak, hogy Prokopios politikai gondolkodásmódja változatlanul jelenik-e meg az életmü egyes darabjaiban, vagy sem, ${ }^{32}$ magunk a platóni Állam politikai téziseinek hatása helyett is sokkal inkább Hérodotos hatását tekintjük meghatározó jelentőségűnek, ${ }^{33}$ továbbá az egyes történetek „valódi” jelentését illetően óvatosabb, helyenként pedig homlokegyenest ellentétes álláspontra helyezkedünk, mint Kaldellis. A továbbiakban ezekről a különbségekről lesz szó.

IV.

Ha a perzsa könyvek irodalmi előképét keressük, kézenfekvőnek látszik, hogy elsősorban Hérodotos művéhez kell nyúlnunk. A halikarnassosi történetíró már csak művének tárgya miatt is tökéletes megoldásnak kínálkozik, hiszen ő szintén a perzsa háborúk, a perzsa nép történetét írta meg. Summa summarum, ha a görög nyelvü irodalomban bármilyen összefüggésben szóba kerülnek a perzsák, biztos, hogy Hérodotos műve megkerülhetetlen előzmény. ${ }^{34}$ Más kérdés, hogy a hérodotosi hatás nyomai hogyan, milyen formában jelennek meg az adott müben. Esetünkben ez a hatás - véleményünk szerint - mind a szerkezetben, mind az egyes történetekben, mind a mondanivaló lényegében egyértelműen tetten érhető, különbség alapvetően csak a terjedelmi kérdésekben mutatkozik. ${ }^{35}$

\footnotetext{
${ }^{30}$ Agathias (praef. 4-5) például hangsúlyozza, hogy a történetírás erkölcsi céljának elérésében az anekdoták jelentősége óriási.

${ }^{31}$ Kaldellis: i. m. (7. jegyz.) 64 megfogalmazása szerint: "Procopius expounds his political thought in a series of largely unhistorical vignettes."

${ }^{32}$ Kaldellis többek között azt kívánja bizonyítani, hogy a Titkos történet kritikus, élesen császárellenes hangja nincs ellentmondásban a korábbi művekben megjelenő szemlélettel, Prokopios gondolkodása koherens egységben értelmezhető. Mindez azonban - akár igaz, akár nem - nem segít a történetek értelmezésében.

${ }^{33}$ A számos párhuzam ellenére túlzásnak tartjuk Kaldellis: i. m. (7. jegyz.) 83 kijelentését: 'Procopius' entire introduction is structured around the teachings of Republic."

${ }^{34}$ Mindezt pontosan tudja Kaldellis: i. m. (7. jegyz.) 73: "Given the centrality of classical sources in the education of literate Greeks during the empire, it was inevitable that they should view first the Parthians and then the Sasanians through the lens of Herodotus' Achaemenids."

${ }^{35}$ Nem térünk ki ezúttal a számos formai párhuzamra. Ezekről lásd például: H. Braun: Die Nachahmung Herodots durch Prokop. Nürnberg 1894.
} 
Néhány példa a párhuzamok közül! Prokopios - akárcsak Hérodotos - a perzsa háborúk bemutatását a háborúhoz vezető előzmények ismertetésével kezdi. ${ }^{36} \mathrm{Az}$ előzményekkel elődjéhez hasonlóan maga is a fokozatos morális hanyatlás folyamatát kívánja ábrázolni, melynek során az igazságos uralkodó helyébe zsarnoki hajlamokat mutató uralkodó kerül. Míg Hérodotosnál a folyamat két végpontján Kyros (ideális uralkodó) és Xerxés (zsarnok) áll, addig Prokopiosnál az erkölcsileg feddhetetlen Isdigerdés lesz az ideális uralkodó, a törvényeket lábbal tipró Kabadés pedig a par excellence zsarnok.

További szerkezeti párhuzamnak tekintjük, hogy Prokopios - akárcsak Hérodotos - szintén kitérőben mutatja be a népeket, melyekkel a perzsák a hódításaik során érintkezésbe kerülnek. Az ephthalitákkal kapcsolatos néprajzi exkurzus elemei ráadásul ugyancsak számos hasonlóságot mutatnak Hérodotos hasonló jellegű kitérőivel. Amikor Perozés hadjáratot indít a fehér hunok ellen, Prokopios is megadja az ephthalita településterület pontos földrajzi kereteit (Gorgó város, Perzsia északi határvidéke), jellemzi a politikai berendezkedésüket (királyság, törvényes államrend), leírja külsejüket (fehér bőr, szabályos arc), ismerteti egy különlegesnek tartott szokásukat (önkéntes emberáldozat). ${ }^{37}$

Prokopios - akárcsak Hérodotos - előszeretettel színesíti a cselekményt mesék, példázatok, tarka történetek elbeszélésével. A prokopiosi betétek változatos felépítést mutatnak: akad köztük körkörösen építkező (Perozés ismétlődő hadjáratai), ${ }^{38}$ keretes szerkezetű (így fogja közre Kabadés története a Felejtés börtönéről szóló exkurzust), és látszólag szervetlenül, vagy lazán kapcsolódó történet is (az oroszlán és a kecske meséje, az igazgyöngy története) - mindez ismét Hérodotos meseszövését idézi.

A bemutatott anekdoták hitelességét Prokopios - akárcsak Hérodotos - olykor maga is megkérdőjelezi. Az egymásba fonódó történetek, tarka epizódok élesen szét nem választható sorozata pillanatnyi benyomásokat ébreszt, hangulatokat villant fel, végül kialakít az olvasóban egy általános képet a perzsákról - miközben talán az önmagukról alkotott kép is pontosabbá válik.

Prokopios természetesen a fenti hasonlóságok ellenére sem nevezhető Hérodotos-epigonnak. Az örökölt módszert átveszi és alkalmazza, a készen kapott anyagot beépíti, más szerzők felhasználásával gazdagítja: de mindezt nagyfokú szabadsággal teszi. Ha úgy fordul, összegyúr két különböző motívumot, máskor átalakít egy történetet, és időnként bizony - mint láttuk - attól sem riad vissza, hogy elrugaszkodjon a történeti tényektől.

Mielőtt néhány konkrét példával illusztrálnánk fenti állításainkat, vessünk egy pillantást a perzsa történeteknek nevezett rész szerkezetére, ebben a kérdésben ugyanis ta-

${ }^{36}$ A különbség leginkább itt is a terjedelemben mutatkozik, mert míg Prokopiosnál csak néhány fejezetet, addig Hérodotosnál négy könyvet tesznek ki az előzmények.

${ }^{37}$ Hérodotos hatalmas történeti korszakot tekint át, kitérői már csak emiatt is gyakoriak és terjedelmesek. Az ephthalita-exkurzus párhuzama - a terjedelmi különbségtől eltekintve - leginkább természetesen Hérodotos skytha-logosa lehetne.

38 A Perozés-történetek szerkezete ismétlődő elemekből építkezik (nagy erejű perzsa támadás, ephthalita csel, perzsa vereség), de ugyanakkor fokoz is (az eskü fejében megbocsátás, de az esküszegésért halál). 
lán tudunk némi újdonsággal szolgálni. Véleményünk szerint a szóban forgó szakasz látszólagos töredezettsége ellenére valójában három egységből, három történetpárból áll. A három rész három különböző szemszögből kívánja bemutatni a perzsákat, miközben időben közeledünk Prokopios jelenkorához, a perzsa háborúk korához, az erkölcsi állapotok pedig az eltelt idővel párhuzamosan folyamatos romlást mutatnak. Az első egység két történetében (Arkadios és Isdigerdés, valamint Anatolios és Uararanés története) a perzsák és a bizánciak (elvileg ez lenne a bevezető tárgya), a második egység két történetében (Perozés első és második hadjárata, közte az igazgyöngy-exkurzus) a perzsák és más barbárok (ephthaliták), a harmadik egységben (Kabadés első és második uralkodása, közte a Felejtés börtöne-exkurzus) pedig már csak a perzsák a főszereplők. Három különböző időpont, három különböző történelmi helyzet, három pillanatfelvétel.

Bár az első egység történetei időben viszonylag közel játszódnak Prokopios működéséhez - Arkadios császár 408-ban, II. Theodosios pedig 450-ben halt meg -, úgy tűnhet, hogy nem pusztán néhány évtized, hanem egy egész világ választja el őket egymástól. Az első történetek perzsa uralkodói már-már az emberiség aranykorát idéző epikus hősök, akiknek jó tulajdonságai és erényes cselekedetei felülmúlhatatlanok. Mikor Isdigerdés mindenféle kényszer nélkül, minden érdektől mentesen vállalja, hogy gondoskodik legfőbb ellensége fiáról, majd példamutatóan eleget is tesz vállalásának, olyan magatartást tanúsít, mely a későbbi királyok esetében már elképzelhetetlen lenne. ${ }^{39}$ Viselkedése eleget tesz az ideális uralkodóval szemben támasztott elvárásoknak: önzetlen, nagylelkủ és lelkiismeretes. Hasonlóan pozitív hős Uararanés, aki saját akaratából képes lemondani a szinte biztos győzelemről és a hódításról, mert így kívánja viszonozni ellensége lenyügöző bátorságát és udvariasságát. Zárójelben jegyezzük meg, hogy Anatolios és Uararanés történetének Kaldellis-féle olvasata jelentősen különbözik a mi értelmezésünktől. ${ }^{40}$ Magunk Anatolios cselekedetében a bátorság megnyilvánulását látjuk (egyedül van, de kiszolgáltatott helyzetéről, a perzsa túlerőről, vállalkozása szinte kilátástalan voltáról látszólag nem vesz tudomást). Ennek megfelelően Uararanés visszavonulását kizárólag a követ hősies fellépésének, nem pedig a bizánciak állítólagos megalázkodásának tulajdonítjuk, amiről - szerintünk legalábbis - nincs is szó a szövegben. Anatolios nem megalázkodik, hanem inkább tiszteletet mutat az ellenfél irányába: erre gondolhatott a perzsa király is, mikor a követ magas rangjában a személyének szóló megbecsülés jelét látta (a görög szövegben a $\tau \iota \mu$ szó szerepel). ${ }^{41}$ Mintha a perzsa királyok nem is birodalmuk érdeke, hanem valamiféle uralkodói körökben megszokott és elvárt „gentlemen's agreement” szerint kormányoznának. Látszólag a római császárok

39 Ennek megfelelően Iustinos császár már nem hajlandó viszonozni a perzsák korábbi nagylelkűségét, elutasítja a Chosroés fölötti gyámságot (I, 11).

${ }^{40}$ Kaldellis: i. m. (7. jegyz.) 68-69 Anatolios magatartását megalázkodásnak ("humility”), a római katonai erő gyengeségének tekinti ("Romans will repeatedly prostrate themselves before a foreign tyrant, unable to resist him with arms"), Uararanés viselkedésében pedig visszalépést lát a perzsák korábbi harciasságához képest ("gradual decline of Persian virtue").

${ }^{41}$ Prokopios talán pontosan azért hallgatta el a perzsa sereg pusztításait, hogy Uararanés alakját kellően pozitív színben tüntethesse fel. 
is az íratlan „lovagi” szabályoknak megfelelően viselkednek (Arkadios képes ellensége kezébe helyezni fia és birodalma sorsát, Theodosios pedig legfőbb emberét egymagában küldi a perzsa sereg fogadására), de a látszat ezúttal is csal. Arkadios ugyanis más lehetőség híján, kényszerből bízik meg Isdigerdésben, ${ }^{42}$ Theodosios pedig nem tudatosan küldi éppen Anatoliost követségbe, hanem véletlenül alakult így. ${ }^{43}$

Ám nem telik bele sok idő, ${ }^{44}$ máris jelentős változás áll be a perzsa királyok magatartásában, egyszersmind megítélésében. Szó sincs immár a korábban képviselt „epikus értékekről”, sőt minden az ellenkezőjére fordul: Perozés meggondolatlan és felelőtlen uralkodó, akitől rettegnek az alattvalói, aki nem képes tanulni saját hibájából, aki megszegi a legszentebb esküt, s végül ostoba viselkedésével serege pusztulását okozza. A Perozés-történetek pozitív hősei nem a perzsák, de nem is a bizánciak - ők az Eusebios-epizódtól eltekintve nem is szerepelnek -, hanem a barbár ephthaliták. Ök testesítik meg azokat az értékeket, melyek ezúttal a perzsákból hiányoznak. Viselkedésük már-már a platóni sarkalatos erényeket idézi fel az olvasóban: kétszer is képesnek bizonyulnak arra, hogy szembeszálljanak az ellenséggel és felülkerekedjenek a jelentős túlerőben lévő perzsákon (bátorság), ráadásul két különböző módon csalják őket tőrbe (bölcsesség), a legyőzött ellenségnek meg tudnak bocsátani (mértékletesség), de az esküszegést megbüntetik (igazságosság). ${ }^{45}$ Az igazgyöngy közbeékelt történetére később még visszatérünk: egyelőre csak annyit, hogy magunk - az általános véleményekkel ellentétben - ezt az elbeszélést tekintjük a perzsa történetek kulcsának. Talán nem véletlen az sem, hogy Prokopios ezt az epizódot a „perzsa történetek” szinte mértani középpontjában helyezi el.

Ami a folytatást illeti, a harmadik egység - ha lehetséges egyáltalán - még kedvezőtlenebb színben tünteti fel a perzsákat. A hanyatlás érzékeltetéséhez ezúttal még csak ellenfélre sincs szükség, Kabadés uralkodása ugyanis a perzsa belviszonyok romlásáról fest árulkodó képet. Nem önmagában a trónviszály a legnagyobb probléma, hiszen ez csak egyenes következménye a Perozés meggondolatlansága nyomán kialakult helyzetnek. ${ }^{46}$ Hogy a baj sokkal mélyebben gyökerezik, azt igazából a szembenálló felek (Blasés és Kabadés) eltérő hatalomfelfogása mutatja meg. Blasés pontosan tudja, hogy Kabadést nem elegendő börtönbe zárnia, hanem - ha jót akar magának - egyszer s mindenkorra

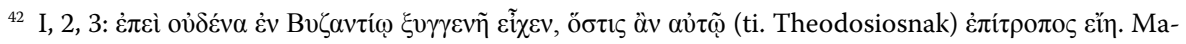
gyarul: „mivel Byzantionban egy rokona sincs, aki gondot viselne rá.”

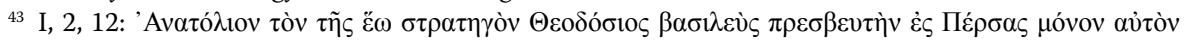

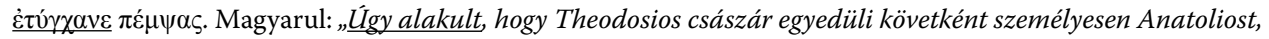
a keleti térség hadvezérét küldte a perzsák elé."

${ }_{44}$ Prokopios két uralkodót (II. Yazdgird, III. Hurmazd) kihagy a felsorolásból, Uararanés (420-438) után nála rögtön Perozés (459-484) következik.

${ }^{45}$ Egyetértünk Kaldellis: i. m. (7. jegyz.) 69-75 fejtegetésével, miszerint az ephthaliták felértékelése egyszersmind a perzsák és a rómaiak barbarizálódását is jelenti.

${ }^{46}$ Bár a történet szerint Kabadés kivételével Perozés összes fia meghalt az ephthalita hadjáratban, a valóságban azonban legalább még egy fiú (Zāmāsp) életben maradt. Prokopios a változtatással talán Perozés felelőtlenségét kívánja még nyomatékosabban hangsúlyozni. 
véglegesen rendeznie kell a kérdést. S bár uralkodóként megtehetné, mégsem végezteti ki, vagy öleti meg kiszolgáltatott ellenlábasát tanácsadói jóváhagyása nélkül, mert még él benne valami a régi perzsa királyok szellemiségéből. Sőt, amikor jó szándékú katonai parancsnoka (chanarangés) és keleti helytartója, Gusanastadés expressis verbis Kabadés meggyilkolását javasolja a tanács színe előtt, Blasés inkább a többség szavának enged, és életben hagyja unokaöccsét, bármennyire is fenyegetést jelent rá nézve a személye. Prokopios azt is elmondja, hogy mi áll a perzsa bölcsek döntésének hátterében $(\mathrm{I}, 5,7)$ :

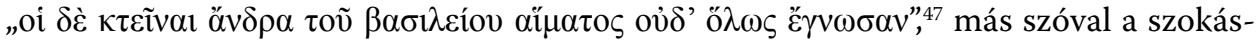
jog, az íratlan törvények betartása fontosabb volt, mint az uralkodó személyes érdeke és biztonsága. Ha felidézzük, hogy a Kabadés elleni lázadást éppen a törvények radikális átalakításának, az ősi szokások megváltoztatásának szándéka váltotta ki, máris világossá válik a két szemlélet közti különbség: míg Blasés saját személyét másodlagosnak tekinti a törvények mindenhatóságához képest, addig Kabadés a király véleményét, szavát, szándékát a törvények fölé helyezi, márpedig számos vétke között (felesége feláldozása, szövetségkötés apja gyilkosaival stb.) éppen ez a legsúlyosabb büne. De - amint az a Felejtés börtönéről szóló kitérőből kiderül - Kabadés hatalomfelfogása sem minden előzmény nélkül való. A kalandos történet elbeszélése, Arsakés megpróbáltatásainak és tragikus sorsának bemutatása, a magusok praktikáinak leírása véleményünk szerint mind-mind azt a célt szolgálta, hogy Prokopios Pakurios személyében megrajzolhassa Kabadés elöképét. Pakurios ugyanis, aki - emlékezzünk vissza - könnyelmü ígéretét követően pa-

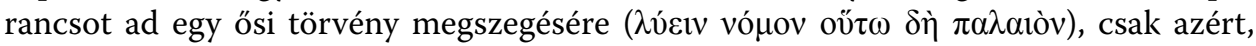
hogy a szavát mindenáron meg tudja tartani (ő $\pi \omega \varsigma \pi \alpha v \tau \dot{\alpha} \pi \alpha \sigma ı v \dot{\alpha} \lambda \eta \theta i ́ \zeta \eta \tau \alpha$ ), ugyanazt a szemléletet képviseli, mint kései utódja. Más kérdés, hogy Kabadésnek szerencséje van. Ö is tesz egy könnyelmű ígéretet, melyet aztán megbán, de mikor ennek ellenére kész

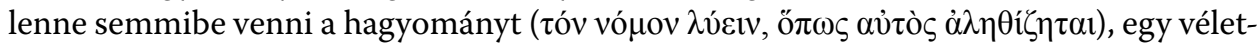
len folytán megmenekül attól, hogy választásra kényszerüljön adott szava és a szokásjog között. ${ }^{48}$ Mindez a lényegen mit sem változtat: Kabadés - ahogy a későbbiek során még inkább kiderül - már valódi zsarnok.

47 „A többiek ennek ellenére úgy határoztak, hogy semmiképpen nem öletnek meg királyi vérből származó személyt."

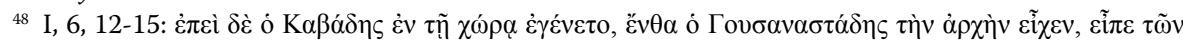

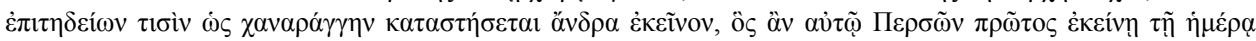

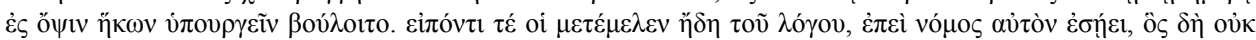

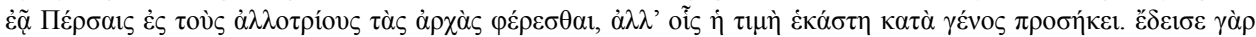

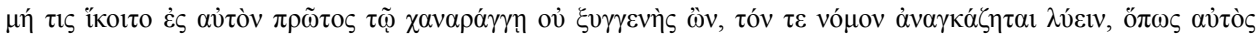

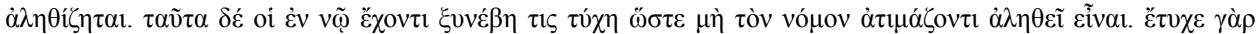

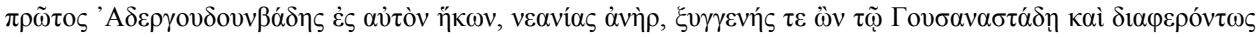

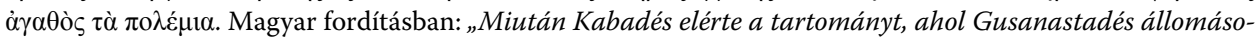
zott, néhány bizalmas embere elött kijelentette, hogy azt a férfit fogja kinevezni chanarangésnek, aki a perzsák közül aznap elsőként járul a szine elé, hogy felajánlja neki szolgálatait. De alighogy kimondta, már meg is bánta az igéretét, mert eszébe jutott egy törvény, ami nem engedi a perzsáknak, hogy bárki másra hivatalt ruházzanak, mint akit az adott rang születése jogán megillet. Márpedig Kabadés éppen attól tartott, hogy elsöként olyan ember kerül elé, aki nem rokona a chanarangésnek, s ö kénytelen lesz eltörölni a törvényt, hogy a szavát 
Végül térjünk vissza Perozés igazgyöngyének lebilincselő történetére, mert - mint mondtuk - véleményünk szerint ez az elbeszélés - ahogy a kagyló az igazgyöngyöt a maga mesébe illő cselekménye ellenére magában hordozza mindazt, amit Prokopios az előzmények bemutatásával közölni kíván. ${ }^{49} \mathrm{~A}$ történet közvetlen forrásait már sokan és sokfelé keresték: mindhiába. ${ }^{50}$ Magunk nem is a források kérdéséből indulnánk ki - bár ezzel kapcsolatban is teszünk javaslatot -, hanem mindenekelőtt a rhétoriskolák tanítási gyakorlatára hívjuk fel a gúnyolódó kritikusok figyelmét. ${ }^{51}$ Egyáltalán nem fontos ugyanis, hogy van-e bármiféle hiteles történeti alapja a beszámolónak, vagy teljes egészében kitalált mesét olvasunk. Ahogyan azt már Aphthonius is megfogalmazta: „a mese kitalált történet, mely az igazságot tükrözi.”22 Mindössze egyetlen kérdést érdemes megvizsgálnunk: milyen igazságra kívánja Prokopios felhívni a figyelmünket?

A válaszhoz érdemes ismét visszakanyarodnunk Hérodotoshoz. Már első olvasásra is feltünik, hogy a Perozés-történet bizonyos motívumai nagy hasonlóságot mutatnak a hérodotosi Polykratés-elbeszéléssel. A történet közismert: a samosi tyrannos, nehogy túlzott szerencséje kiváltsa az istenek irigységét, barátja tanácsára elhatározza, hogy megválik legértékesebb tulajdonától. Ám hiába dobja a tengerbe kedvenc gyűrüjét, hiába próbálja megváltoztatni saját sorsát, egy halász jóvoltából az ékszer mégis visszakerül a kezébe. Polykratés tragikus halála végül igazolja a baljós előjeleket: a tyrannos az anyagi haszon reményében fittyet hány a veszélyre, nem törődik a többszöri figyelmeztetéssel, meggondolatlanságáért pedig az életével fizet (III, 39-43; III, 120-125).

A Polykratés- és Perozés-elbeszélés egyes elemei között a hasonlóság nyilvánvaló: mindkét esetben szerepel egy becses ékszer (gyürü, illetve fülbevaló), felbukkan a tenger-motívum (Polykratés a tengerbe dobja, Perozés a tengerből szerzi ékszerét), fontos szerepet játszik egy halász (ő juttatja vissza, illetve gyüjti be a kincset), mindkét uralkodó megpróbálja eltüntetni ékszerét (Polykratés a vízbe hajítja, Perozés meszszire dobja), mindkét történet tragikus halálesettel végződik (Polykratés a kereszten, Perozés az ephthaliták vermében végzi). Ugyanakkor a párhuzamok mellett - kár lenne tagadnunk - a fontos különbségek is szembetűnőek. Perozést például Polykratésszel ellentétben kizárólag a gyöngy megszerzése, az anyagi haszon motiválja, ő meg sem próbál tenni a sorsa ellen, hanem vakon rohan a végzetébe. Bár a halász alakja mindkét elbeszélésben feltűnik, a szereplő funkciója jelentősen eltér: Hérodotosnál pusztán a

megtarthassa. Miközben ezen töprengett, egy szerencsés véletlen úgy hozta, hogy a törvény megsértése nélkül teljesithette az igéretét. Elsőként ugyanis egy fiatalember érkezett a szine elé, Adergudunbadés, aki történetesen rokona volt Gusanastadésnek, mellesleg kiváló katona."

${ }^{49}$ Kaldellis: i. m. (7. jegyz.) 75-80 szintén fontosnak ítéli a gyöngy történetét, de elemzésében más mo-

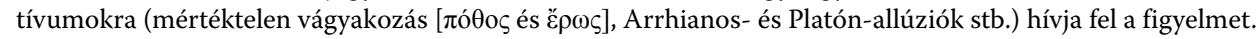

50 Vö.: Cameron: i. m. (6. jegyz.) 154-155.

51 Vö.: C. Mango: Byzantium. The Empire of New Rome. New York 1980. 243: "Ludicrous anecdote about a swimming oyster that was pursued by a shark."

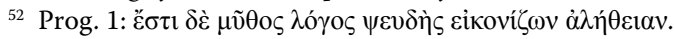


sors eszköze, a történet lényegét nem befolyásoló mellékszereplő, aki akarata ellenére szerzi vissza ura eldobott gyürűjét, Prokopiosnál viszont főszereplő, az erkölcsi tanulságot megfogalmazó és kimondó bölcs válik belőle. A párhuzamok ellenére a számottevő eltérések tehát arra mutatnak, hogy a Perozés-történet más forrásból is merített, nem kizárólag a Polykratés-anekdotára támaszkodott. Ez a másik forrás pedig véleményünk szerint Hérodotos Kroisos és Solón története, mely talán még a Polykratés-történetnél is ismertebb és népszerübb.

Amint az köztudott, Kroisos, a mérhetetlen gazdagságáról híres lyd király egy ízben vendégül látta udvarában Solónt, az athéni bölcset. Kroisos megmutatta a kincseit vendégének, majd az elismerésére vágyva megkérdezte tőle, kit tart a világ legboldogabb emberének. Mivel Solón kétszer is kiábrándító választ ad - először az athéni Tellost, majd az argosi testvérpárt, Kleobist és Bitónt nevezi meg -, az ingerült uralkodó magyarázatot követel a bölcstől. Solón hosszú beszédben fejti ki a boldogságról, illetve az élet céljáról vallott nézeteit. Véleménye szerint a gazdagság önmagában nem jelent boldogságot, a szerencse forgandó, csak az ember életének a végén derül ki, hogy boldog volt-e, vagy sem. Kroisos csalódottan elbocsátja vendégét, s csak jóval később, Kyros máglyájára lépve érti meg végre Solón bölcsességét (I, 29-33; I, 86-87).

Annyi hosszadalmas elemzés nélkül is világosan látszik, hogy mikor Prokopios halásza maga is rangsort állít az ember számára fontos értékek között, a Solónéhoz nagyon közeli álláspontra helyezkedik. A halász - a történetbe látszólag szintén önkényesen és céltalanul illesztett beszédében - valóságos életfilozófiát közöl a kapzsi Perozésszel. Állítása szerint az anyagi javak, melyek miatt az embert általában boldognak mondják, csakugyan fontosak ( $\pi \circ \theta \varepsilon ı v \grave{\alpha} \mu \grave{\varepsilon} v \dot{\alpha} v \theta \rho \omega ́ \pi \omega \chi \rho \eta ́ \mu \alpha \tau \alpha)$, de nála is csak a harmadik helyre kerülnek a kívánatos dolgok képzeletbeli dobogóján. A pénznél ugyanis fontosabb az

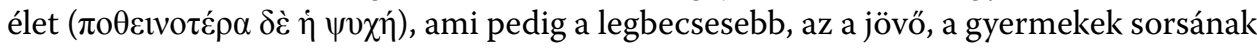

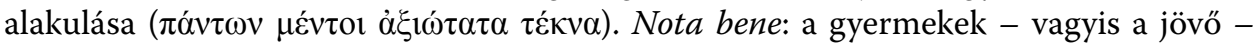
mint a boldog élet szükséges feltételei már Hérodotosnál is hangsúlyosan jelennek meg. Először a legboldogabb embernek nevezett Tellosról tudjuk meg, hogy kiváltságos helyzete nem valamiféle különleges okból fakad, mindössze (I, 30) „szép és kiváló gyermekei

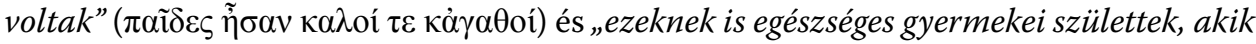

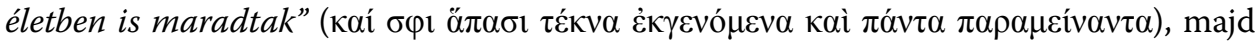
később a szegénységet megszépítő előnyök között olvasunk a „szép gyermekekről” (I, 32:

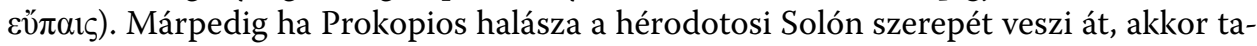
lán Perozés alakjában sem alaptalanul keressük Kroisos kései követőjét. S csakugyan: Perozés hangsúlyozott anyagiassága, meggondolatlanul kezdeményezett katonai akciói, végül bukása mind-mind a lyd uralkodó sorsát idézik. Hiába figyelmezteti a halász, hogy a gyermekeinél, a jövőnél nincs fontosabb, Perozés maga okozza - egy híján - összes

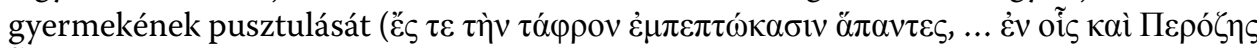

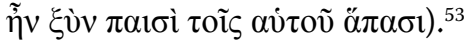

${ }^{53}$ „Mindnyájan az árokba zuhantak ... köztük volt Perozés is valamennyi gyermekével együtt.” 
Az igazgyöngy-exkurzus valódi jelentését tehát abban látjuk, hogy Prokopios itt jelöli meg a perzsa történetekben ábrázolt erkölcsi romlás okát, ami nem más, mint a helyes értékrend összezavarodása. A birodalom - nemcsak a perzsa! - csakis addig lehet sikeres, míg az uralkodó a helyes értékrendnek megfelelően, igazságosan és törvényesen kormányoz (Isdigerdés és Uararanés). A hanyatlás az értékrend megváltozásával, az anyagi javak túlértékelésével kezdődik (Perozés): ez a változás már önmagában is súlyos következményekkel jár (gyermekek halála, a jövő veszélyeztetése), de az igazi katasztrófa csak akkor következik be, ha az uralkodó akarata, érdeke, szeszélye a törvényeknél is fontosabbá válik (Pakurios, Kabadés). Ezt a folyamatot, a zsarnokság kialakulásának természetrajzát mutatja be a hérodotosi előzményekből építkező Prokopios a perzsa anekdotákban.

\section{SUMMARY}

At the end of the preface of his historical work, Procopius outlines a history of the relationship between Byzantium and Persia. This part of his work (De bellis I, 2-6), which consists of a series of anecdotal episodes, tales, and fictitous stories, has been regarded by scholars as an entertaining compilation lacking historical credibility. The aim of this paper is to present these anecdotes, the so-called "Persian histories", and to analyze the structure and the function of the stories. In our opinion, Procopius uses the literary techniques of Herodotus to illustrate the moral decline which led to the war.

Keywords: Procopius, Persian war, anecdotes, Herodotus

MÉszÁros TAMÁs

ELTE Eötvös József Collegium

1118 Budapest, Ménesi út 11-13.

tamas.m.meszaros@gmail.com 